\title{
ECOTOURISM AND RURAL LIVELIHOOD OPPORTUNITIES IN EAST KHASI HILLS DISTRICT, MEGHALAYA
}

\author{
Martius Ryngiasaid Rynjah ${ }^{1}$ \\ ${ }^{1}$ Martius Ryngiasaid Rynjah is a Ph.D Scholar \\ in the Department of Social Work, \\ Mizoram University, \\ Aizawl, Mizoram, India.
}

\author{
* Grace Lalhlupuii Sailo ${ }^{2}$ \\ ${ }^{2}$ Grace Lalhlupuii Sailo is an Assistant \\ Professor in the Department of Social Work, \\ Mizoram University, \\ Aizawl, Mizoram, India.
}

*Corresponding Author

Article DOI: https://doi.org/10.36713/epra6958

DOI No: 10.36713/epra6958

\begin{abstract}
Meghalaya is one of the states in North-east India that is blessed with beautiful and mesmerising natural scenic beauty. The undulating green hills, pleasant breeze, waterfalls gushing from the mountains, complimented with cool climatic condition is the best combination for nature loving tourists to experience. This paper identifies the livelihood opportunities that ecotourism has provided to the local communities. Three villages i.e., Mawlynnong, Riwai and Mawsmai has been selected for the study. Purposive Sampling was adopted to identify households engaged in ecotourism activities. Primary data was collected from the households that are engaged generating livelihood from Ecotourism related activities. There are a wide range of ecotourism related activities that are being engaged by the local community members to generate income. There are also livelihood activities engaged by the respondents that has a scope for providing employment for other community members as well. In the context of the three villages selected, ecotourism has served as both primary and also secondary sources of income for the local communities. it is evident that ecotourism has played a major role in promoting livelihood and village economy in the three villages. Ecotourism has the potential for the enhancement of rural livelihood through more innovative, sustainable and eco-friendly practices.
\end{abstract}

\section{INTRODUCTION}

There are a variety of ecotourism definitions such as nature travel, nature-orientated tourism, nature tourism, nature-based tourism, sustainable tourism, alternative tourism and special interest tourism (Laarman \& Durst, 1987; Durst \& Ingram, 1988; Wilson \& Laarman, 1988; Valentine, 1992; Hall \& Weiler, 1992; Diamantis,1998a). According to the TIES (2006), ecotourism is another segment of the tourism industry that focuses on exploring the untouched and remains of natural areas (I Nee \& I Beckmann, 2011).

Mass tourism was the common form of tourism practiced in the initial development stage of tourism. It was also expected that this would also bring about growth in the economy in forms of foreign exchange and GNP growth, tax revenue and employment (Lascurain, 1996); however, it had led to various problems and effects like environmental, economic and socio-cultural degradation. Due to the development of mass tourism, much of the funds and subsidies are being allocated to tourism industry that favours tourists and leaving the other programmes and industries that are benefitting the locals. According to Brown in O'Neil (2002), during the 1980 s, many argued that there was a need for another alternative to tourism as it has negative impact on the environmental, economic and socio-cultural aspects of the host communities. A call for 'alternative tourism' was highly demanded on the basis that its policies should not only consider economic growth but also environmental quality and welfare of the local people.

This gave rise to the environmental movement which demanded from the government to specially allocate separate land for animals and the ecosystem and as an opportunity for people to visit and admire the 
wildlife in its natural beauty and hence help in protecting more areas and species. With this, they established the linkage between tourism, environment exploration and protection and paved way for the development of ecotourism (Ceballos-Lascurain, in O’Neil; 2002).

Jamieson. W., etal (2004), view tourism as a tool for alleviation of poverty where both the individual and the community collectively can benefit through tourism. It focuses on the idea that tourism as an industry can be used as a pro-poor approach. They promote the idea for the need of a paradigm shift for tourism from just being an industry to being a pro-poor approach which has the potential to bring about socio-economic changes for the local communities.

Ecotourism development has brought about benefits such as improvement in livelihood, employment opportunities, improved income and reduced vulnerability. Livelihood improvement have contributed to diversification of livelihood options reduced dependency on the degrading natural resources. On the other hand, due to tourism development, new aspects of vulnerability like displacement and over dependency on tourism has negatively affected the locals (Boer, 2012). Meghalaya which is often called Switzerland of the East is a tourist hotspot, housing several attractive and interesting sites that has been attracting tourists for a long time. Many natural wonders have been opened up as ecotourism sites and this has led to many local people engaging in livelihood activities that involve ecotourism.

\section{METHODS AND MATERIALS}

The study seeks to explore into the various livelihood opportunities brought about by ecotourism development in two selected villages of Meghalaya and understand the impact of tourist development on the traditional livelihood of the host communities. It also seeks to explore the scope of livelihood diversification with the existence of ecotourism practices.

The study adopts a descriptive research design employing both quantitative and qualitative research methods. Primary data is collected through Survey using pre-tested semi structured interview schedule from Mawlynnong, Riwai and Mawsmai villages, East Khasi Hills District, Meghalaya. Systematic random sampling has been used to identify the sample households from each village. Only those households involved or engaged in ecotourism activities as an income generating activity are included in the sample. The key areas that have been identified in the study are age, gender, primary and secondary source of income, livelihood diversification and the traditional livelihood practices.

\section{RESULTS AND DISCUSSION}

The findings have revealed that ecotourism practices have brought about a positive impact on the rural livelihood of the community in the three villages included in the study.

\begin{tabular}{|c|c|c|c|c|}
\hline \multirow{2}{*}{ Age Group } & \multicolumn{4}{|c|}{ Gender } \\
\cline { 2 - 5 } & Male & $\mathbf{\%}$ & Female & \% \\
\hline$(20-30)$ Years & 19 & 15.97 & 20 & 16.81 \\
\hline$(31-40)$ Years & 17 & 14.29 & 24 & 20.17 \\
\hline$(41-50)$ Years & 4 & 3.36 & 10 & 8.4 \\
\hline$(51-60)$ Years & 9 & 7.56 & 12 & 10.8 \\
\hline 61 Years and Above & 0 & 0.00 & 4 & 3.36 \\
\hline Total & 49 & 41.18 & 70 & 58.82 \\
\hline
\end{tabular}

Table- 1: Age Group and Gender Distribution of Respondents

The above (Table 1) shows that majority of the respondents are in the age group of $31-40$ years $(34.50$ $\%$ ), followed by $20-30$ years $(32.80 \%)$ while only a small proportion $(8.4 \%)$ are in the $41-50$ years age group. The older respondents $(51-60$ years) consist of a tenth (10.8\%) of the respondents while 61 and above constitute $3.36 \%$ of those engaged in tourism related livelihood activities. It can be inferred that the presence of ecotourism practices in the villages has brought about opportunities for employment and livelihood generation for youth and young adults in the villages. For each of the age groups, females engaged in ecotourism are more than their male counterparts which indicates that Ecotourism has led to economic empowerment of women folk in rural community which has considerably changed the traditional beliefs and attitudes towards women's 
contribution to family economy. A similar finding by Irandu and Shah (2014) shows how most women in Kenya are benefitting from ecotourism which has a great potential in bringing about social and economic empowerment to women and the community.

\begin{tabular}{|c|c|c|}
\hline Sources of Primary Income & Frequency & $\mathbf{\%}$ \\
\hline Tourism & 55 & 46.2 \\
\hline Labourer (Masonry) & 20 & 16.8 \\
\hline Business & 12 & 10.1 \\
\hline Farmer (others land) & 9 & 7.6 \\
\hline Farmer (own land) & 9 & 7.6 \\
\hline Teacher & 7 & 5.9 \\
\hline Government & 4 & 3.4 \\
\hline Shop Keeping & 2 & 1.7 \\
\hline Electrician & 1 & 0.8 \\
\hline Total & $\mathbf{1 1 9}$ & $\mathbf{1 0 0}$ \\
\hline
\end{tabular}

Table- 2: Primary Source of Income of the Respondents

Table 2 shows the distribution of the primary source of income of the respondents engaged in ecotourism related livelihood activities. For a majority of the respondents $(46.2 \%)$, ecotourism related livelihood activities is the primary source of livelihood followed by a sixth $(16.8 \%)$ who are daily wage labourers and a tenth $(10.10 \%)$ who own petty businesses. Only a few $(15.2 \%)$ practice agriculture even though these villages are located in the rural areas of the District. The respondents engaged in the service sector (teaching and government service) comprise less than a tenth $(9.3 \%)$ of the total respondents.

Ecotourism related activities have served as the main source of income for most of the respondents in the study. There is a decline in the traditional livelihood i.e., agricultural practices in the villages as people focus on tourism as an important source of family economy. On the other hand, there is a concern in the human resource sector as very few respondents are engaged in the service sector.

A study conducted in Ghana found that despite the presence of ecotourism in the region, agriculture or farming activity has not been replaced by tourism and is a supplementary activity to the people; and is not the primary means of generating livelihood for the communities (Agyeman, 2005). On the contrary, a study by Guha (2007) found out that even though the locals reside in close proximity to the tourism destinations, their primary economic activity is not always dependent on tourism rather it is seasonal in nature but has very much contributed to improved income of the locals who are involved in tourism related livelihood activity.

\begin{tabular}{|c|c|c|}
\hline Sources of Secondary Income & Frequency & $\mathbf{\%}$ \\
\hline Tourism & 62 & 52.1 \\
\hline Farmer (others land) & 19 & 16 \\
\hline Labourer (Masonry) & 12 & 10.1 \\
\hline Not Applicable & 11 & 9.2 \\
\hline Farmer (own land) & 10 & 8.4 \\
\hline Business & 4 & 3.4 \\
\hline Others & 1 & 0.8 \\
\hline Total & $\mathbf{1 1 9}$ & $\mathbf{1 0 0}$ \\
\hline
\end{tabular}

Table- 3: Secondary Source of Income of the Respondents

The secondary sources of income of the respondents engaged in ecotourism activities is shown Table- 3 . Tourism related livelihood activities has provided supplementary income for a little more than half $(52.10 \%)$ of the respondents. While almost a tenth $(9.2 \%)$ do not have secondary income sources, agricultural practices (on 
others'/rented land) contribute to secondary income for a sixth $(16 \%)$ of the respondents. Less than a tenth $(8.4 \%)$ practice agriculture on their own land.

It can be inferred that ecotourism related livelihood activities has a dominant role in the livelihood of the respondents as both primary and secondary sources of income. With very few respondents practising agriculture, the decline in agricultural practices in the villages paves way for investigation on the aspect of landholding system, soil productivity and agricultural vulnerabilities in these villages.

Mbaiwa (2008) analyzed the changes in rural livelihood before and after tourism development in Botswana where he found that rural livelihoods and conservation of resources have improved and the residents have also inculcated positive attitude towards tourism development and conservation as compared to some decades ago when they were not involved in tourism development. On the negative side the residents became too dependent on tourism development causing a decline and almost forgoing their traditional livelihood practices.

\begin{tabular}{|c|c|c|}
\hline Nature of livelihood activities & Frequency & Percent \\
\hline Homestay & 33 & 27.7 \\
\hline Restaurant/Food Stall & 27 & 22.7 \\
\hline Souvenir Shop & 27 & 22.7 \\
\hline Grocery Shops & 16 & 13.4 \\
\hline Petty Shops & 8 & 6.7 \\
\hline Guest House & 3 & 2.5 \\
\hline As a Guide & 2 & 1.7 \\
\hline Hotels & 2 & 1.7 \\
\hline Resort & 1 & 0.8 \\
\hline Total & 119 & 100 \\
\hline
\end{tabular}

Table- 4: Nature of Livelihood Activities within Ecotourism

Table- 4 shows the diversity of ecotourism related livelihood activities that respondents in The data in the above figure shows us the wide range of economic activities that respondents from Riwai and Mawlynnong villages are engaged in. More than a fourth $(27.7 \%)$ provide a Homestay while restaurants and opening a souvenir shop was mentioned by $22.7 \%$ each of respondents. Other activities also include grocery shops $(13.4 \%)$ and petty shops $(6.7 \%)$ for tourists to buy their needs. Very few acts as Tourist guides $(1.7 \%)$, work in hotels $(1.7 \%)$ and resorts $(0.8 \%)$.

Similar findings can be found in a study conducted in Ghana where local communities were able to diversify their livelihood activities by engaging in making local styled guest houses and engaged selling of local souvenirs were the main income generating activities (Wuleka et al., 2012). The introduction of tourism has helped the indigenous communities to diversify livelihood strategies, whether regular or seasonal, through both collective and individual enterprises; restaurants, homestays, café, food stalls, handicraft stores and campsites (Tao, 2016).

There is wide scope for rural folk to diversify and widen ecotourism related livelihood by adding ecofriendly adventure activities that will draw tourists while also increasing their own income. Munugre (2015) identified a wide range of tourism activities offered to tourists such as agro-tourism, nature walking, cycling, cultural tourism and business marketing (selling of arts and handicrafts in local market). Njole (2011) conducted a study in Tanzania where he found that tourism has created job opportunities for the community members for employment as well as it is the major contributor of economic benefits to the community than any other sector, provided employment opportunities, infrastructural development and even educational sponsorship. Susan (2011) found that most of the natural resources were the main assets of the villagers while the creation of protected areas was the main constraints to livelihood of the villagers. The coping strategies adopted by the villagers were agricultural diversification, alternative means of livelihood activities like fishing, hired labour and petty trading.

\section{CONCLUSION}

Common livelihood activities of the rural households such as homestay, restaurants, gift shop, grocery shop and petty shops are activities that help respondents to derive livelihood from tourists and also at the same time they have the scope to provide employment to others in the community in the forms of housekeepers in homestays, helpers in restaurants and grocery shops. Tourism industry has a dominant role as the major economic activity practised by the respondents gradually replacing the traditional livelihood i.e., agriculture. It has contributed to the growth and development of the village economy by offering its influence to operate a wide variety of services and activities associated with ecotourism that would help host communities gain economic benefits. 
The development and growth of tourism industry in the villages in East Khasi Hills District of Meghalaya have created opportunities for employment of youths in the village and also created space for livelihood generation through engagement in various activities associated with tourism in the village. Tourism has also proved to enhance women empowerment in the selected villages. Tourism has played an important role in the three villages in the form of primary as well as secondary source of income for the host communities. The presence of ecotourism practices in these villages has also contributed in diversification of livelihood options for the local communities. There is huge scope for rural households to increase their livelihood outcomes through more innovate and income-generating tourism activities which at the same time are eco-friendly and sustainable.

\section{REFERENCES}

1. Mbaiwa, J. E. (2008). Tourism Development, Rural Livelihoods, and Conservation in the Okavango Delta, Botswana. Retrieved from - http://oaktrust.library.tamu.edu/bitstream/handle/1969.1/etd-tamu-3064/mbaiwadissertation.pdf? sequence $=1$. Accessed on - 21-08-2017

2. Nee, I. \& Beckmann, I. (2011). A Papathanassis (Ed.), The Long Tail of Tourism, Springer, Science DOI 10.1007/978-3-8349-6231-7_13

3. Njole, M. (2011). Tourism for Sustainable Local Livelihood and Nature Conservation: A Case of Lake Manyara National Park. Retrieved from http://edepot.wur.nl/176367,

4. O'Neill. A. C. (2002). What Globalization Means for Ecotourism: Managing Globalization's Impacts on Ecotourism in Developing Countries. Indiana Journal of Global Legal Studies, 9(2). pp. 501-528, http://www.jstor.org/stable/20643839. Accessed on - 21-08-2017

5. Susan, N. N. (2011). Biodiversity Conservation, Ecotourism and Rural Livelihoods in Protected Areas Case Study: The Mount Cameroon National Park. Retrieved from - www.statisk.umb.no/ina/studier/moppgaver/2011Nkengfack.pdf. retrieved on - on 10.08.2017

6. Tao, T. Ch. (2006). Livelihood Strategy in Indigenous Communities Taiwan. Indian Streams Research Journal, 1(V) pp.1-4. doi: 10.21 12/si61-00l

7. Wuleka et al., (2012). Community-Based Ecotourism and Livelihood Enhancement in Sirigu, Ghana. International Journal of Humanities and Social Science, 2(18). Retrieved from - www.ijhssnet.com. Accessed on 21-08-2017

8. Agyeman, Y. B. (2005). Assessment of Ecotourism Impacts on Rural Livelihoods: Basis for Exploring Its Potential for Poverty Alleviation A Case Study of Kakum National Park in Ghana, http://edepot.wur.nl/184638, Accessed on 21-08-2017

9. Irandu, E. \& Shah, P. (2013). The Role of Ecotourism in Promoting Women Empowerment and Community Development: Some Reflections from Kenya, https://www.researchgate.net/publication/301814943_The_Role_of_Ecotourism_in_Promoting_Women_Empower ment_and_Community_Development_Some_Reflections_From_Kenya.DOI: 10.17265/2328-2169/2014.06.002

10. Guha, I. (2007). Does Tourism Contribute to Local Livelihoods? A Case Study of Tourism, Poverty and Conservation in the Indian Sundarbans, SANDEE Publications, Nepal.

11. He, G. et al., (2008). Distribution of Economic Benefits from Ecotourism: A Case Study of Wolong Nature Reserve for Giant Pandas in China, Environmental Management 42, 1017 (2008). https://doi.org/10.1007/s00267-0089214-3

12. Jamieson et al., (2004). Contribution of Tourism to Poverty Alleviation: Pro-Poor Tourism and The Challenge of Measuring Impacts, https://www.researchgate.net/publication/266008511_'Contributions_of_Tourism_to_Poverty_Alleviation_ProPoor_Tourism_and_the_Challenge_of_Measuring_Impacts', Accessed on February $2^{\text {nd }} 2021$.

13. Boer, I. D. (2012). Tourism as Alternative Livelihood: Grassroots Perspectives and Experiences, https://edepot.wur.nl/222213, Accessed on February $2^{\text {nd }} 2021$.

14. Munugre, S.E. (2015). The Impact of Tourism Activities to The Local Communities: A Case of Mto Wa Mbu Ward in Monduli District, http://repository.out.ac.tz/1465/, Accessed on February $2^{\text {nd }} 2021$. 